of a substantial depth of fill in the original post-glacial drainage channel. Although the nature of the major portion of these buried sediments is unknown it is qu ite conceivable that the stratified fluvial sediments of the lowest part of the profile (Fig. 3 ) constitute part of this series. The presence of this well-stratified coarser material indicates that the valley may have contained a stream of much greater magnitude than at present. The implication is that a rainy climate would be necessary to provide such a great volume of stream flow unless the valley was still active as a glacial spillway. The profile reveals that the change from fluvial sediments to flood plain silts is so abrupt as to suggest sudden changes in depositional conditions. Perhaps this has considerable climatological significance. The presence of broad black zones (thick soil profiles), small concentrations of white mineral salts in the silt, leaching of only minor extent and the relative lack of coarse sediments and definite stratification suggest that arid conditions prevailed during the deposition cycle represented by the major portion of the terrace. Fortunately the time of the commencement of this cycle may be approximated owing to the fact that the hearth site, dated at $5200+130$ years, lies only five feet above the base of the buff silt zones.

Postulations as to events responsible for the creation of the terrace are more difficult. Obviously, depositional conditions of a minor nature prevailed in the valley during the formation of the buff silt-zone. A subsequent erosional cycle is necessary to explain the reduction of the valley floor to a depth in excess of 15 feet, creating the lowest terrace Theorizing as to reasons for thi change, we must consider such fac tcr 3 as an increase in stream gradien a drcp in base level, a break-throug down-stream, a change in sedimen tary load of stream water or increas in vclume of water carried by th valley. The adaptability of the fourt and fifth factors, with emphasis o. the fifth, may be a pertinent aspect i acceptance of any theory. Any in crease in volume of water suggest: of course, a climatic change to con ditions of relatively higher precipita tion.

In order to gain a greater ap preciation of the significance of th depositional sequence we must con sider. the conditions which are pre vailing at present. The present-da rate of precipitation is so low in th upper region of the Souris drainag system that the meander channel, $\mathrm{i}$ the region of the site, is large enoug to contain all but the severest $c$ seasonal floods. Without a substan tiating study of the valley sediment we can state only that deposition $c$ the flocd plain variety appears $t$ be taking place at a very slow rat A brief perusal of the climatologic: studies of other authors (Antev 1955 ; etc.) tends to indicate th probability of a direct correlatio with the climatic history evidence in more southerly areas of th continent.

\section{LITERATURE CITED}

ANTEVS E. 1955. Geolcgic Climatic Dati1 in the West. American Antiquity, 20:31 335.

SYMONS, R. D. 1956. Where is the Kit Fo Blue Jay. 14: 63-65.

WETTLAUFER, B. 1955. The Mortlach Sit Anthropological Series No. 1. Departme of Natural Resources, Regina.

1957. The Long Creek Site. Blue Jay, 1 167-169.

\title{
The Role of the Archaeological Society
}

\author{
by Henry W. Hamilton, Secretary. Missouri Archaeological Society, \\ Marshall, Mo.
}

\section{INTRODUCTION}

Henry W. Hamilton is a business man who has long been an amateur archaeologist and an active member of the Missouri Archaeological Society. He is secretary of this organization which is recognized as one of the most successful societies of its kind. Mr. Hamilton is also a membe of the National Committee for the Re covery of Archaeological Remains. $F$. has kindly consented to write th article especially for the Blue Jay, recognition of our own interest an archaeological programme at tl 
Saskatchewan Museum of Natural History. In this regard $\mathrm{Mr}$. Hamilton has written: "I notice that in your rea the archaeological work is being lone by a museum. Had it been a museum in our case, instead of the iniversity, we would have supported unds for the museum. The important hing is that a society support whatver institution may be present in heir area to do the work." Because f the tremendous amount of archaelogical work to be. done in the proince, the Museum needs the active upport of all interested individuals nd societies. Public support is also eeded for the establishment of an ffective archaeological programme $t$ the Museum. In view of the recent ailure of the Department of Natural Resources to secure funds for an rchaeologist and a programme at the Museum, we urge all readers of the Blue Jay and their friends, who are nterested in promoting an archaeoloical research programme, to express heir views in writing to the Editor.d.

On a gray December day in 1934 bout a dozen people from over the he state met in a building on the ampus of the University of Missouri $t$ Columbia and organized what was become the Missouri Archaeoloical Society. From this meager beinning 24 years ago a society of ,400 members has grown.

The objectives of the Society, as tated in the constitution and byaws at that first meeting, were to reserve the remains of the prehisoric people of Missouri, to study hese remains scientifically, to pubsh information about them, to proide both amateur and professional rchaeplogists with opportunities to iscuss their common interests, and arouse public opinion to an appreiation of our prehistcric past.

Another objective, and a primary ne although it was not stated in the ritten goals of the Society, was to et an archaeologist on the staff at he University of Missouri.

Up to that time the only archaeogical work that was being done in he state, chiefly survey, was being orrelated and carried out by two niversity faculty members as a urely spare time activity, since hey were in the departments of hisory and sociology. This work had, owever, proved that amateurs and those even slightly interested in archaeology could make valuable contributions to the knowledge of the subject if their work were given purpose.

But all these objectives of the new group took money and that was what the Society didn't have. With the growing support out over the state however, and some interest among the faculty members themselves, the President of the University soon scraped a small amount of funds together. Although these funds did little more than provide food for the season, in 1935 the first University of Missouri field party, consisting of two men, went to the country. They worked on survey and some excavation, and this achievement was met with enthusiasm by the members of the newly organized group.

It was quite evident, however, that one of the primary responsibilities of a state archaeological society was to take the lead in helping to provide funds to carry on the work, so the society did a little further organizing. University appropriations had to be supported before the Legislature in order to get an archaeologist on the staff. An item of Archaeological Research had to be supported and achieved in crder to make possible the necessary field work. One objective was accomplished about two years later when an archaeologist was employed and field work started in earnest a little later.

As time went on it became even more apparent that the study of American archaeology is something that cannot wait, for civilization with its construction and business activities is rapidly abliterating all prehistoric evidence. One hundred years from now there probably just won't be any archaeology left. In time this problem was recognized nationally by the creation of the Inter-Agency Archaeological Salvage Program.

So now there was a federal archaeological salvage and research program to support, a program recognized by Congress, and the Missouri Society along with many other societies has given regular and consistent support.

During the year 1957, after 23 years of existence of the Society, the University of Missouri had five field parties at work. Some of these were quite small, some quite large. Some were purely the result of state effort and 
scme were almost wholly the result of the national Inter-Agency Archaeological Salvage Program.

But public support of archaeological endeavor is not a one-way street; it bring a responsibilities upon the individuals who are working in the profession. The professional archaeologist must do for his business what all successful private businesses and most professions do. He must have the willingness, the ability, and the stamina to do the extra work wi the public in order to merit and ke this support. He must know his su ject, as well as sufficient about $r$ lated matters with which he must times deal, so that he can speak a write "English" in his work and nct fall into a general jargon of sti ed terms frcm which it is impossib to get concise meaning. He must $\mathrm{g}$ a dollar's worth of effort for eal dollar spent. This is particularly tr since he is spending public funds.

\section{LETTERS}

\section{Memorial to Eva S. Mudiman}

While looking through my wife's notes I found two articles written on a trip we made to Dawson from Whitehorse on July '1st and 2nd, 1956

I am sending them in as a memorial to Eva S. Mudiman. Albert W. Mudiman, Whitehorse, Yukon.

EDITOR'S NOTE: We wish we could print the two articles in which Mrs. Mudiman describes the road to Mayo and Dawson, and Dawson City itself. Here is her colourful description of the flowers along the Dawson road: "Here on July 1, the wild flowers are growing profusely in the woods and bordering the highway. Nature has a lovely selection of colour in her summer garden. Violetblue of Arctic lupin, forget-me-not colour of American bluebells mingle with snowy clusters of Labrador tea; wild roses shading from deep rosy red to the palest pink grow beside the greenish-white northern bedstraw and the common yarrow often takes on a delicate shade of pink or mauve. The campanula spreads its purple bells along the sandy ridges while bright yellow splashes of arnica, golden ragwort and cinquefoil highlight the scene. It is delightful to find the dainty plants of the wild bleeding heart, nodding in the breeze along the road nearing Dawson and the Klondyke river. The magenta of the brilliant vetch and the first blooms of fireweed add a rich final glow to nature's summer tapestry."

\section{Unusual Encounters}

I hope scme of the readers of $t$ Blue Jay will be interested in a fo cf my experiences with birds and ar mals. One evening last summer wh my brother-in-law and I were dri ing along at dusk in the car, we $h$ the frightening experience of sudde ly sceing a large pair of eyes pop in the middle cf the road about feet ahead of us. I slammed on $t$ brakes and we got out of the car see whether we had run over sor domestic animal. To our surprise found absolutely nothing, not even track in the dust on the road. couldn't have been just our imagin tion because we had both seen $t$ same large pair of eyes gleam at for a second and then disappear. I went back to the car and walk around to the front, where we we greeted by a clap, clap, clap. The: lodged quite helpless in the grill, $w$ a lcvely large Great Horned $\mathrm{O}$ clapping his beak at us. We took t: owl home and released it the ne morning when we could see that was unhurt.

A year ago last June, I was wor ing up a stubble field for summe fallow when out fluttered a shar tail from beneath the tractor. I i vestigated and found the nest, whi the discer had buried deep in $t$. loose earth. I dug out the eggs, findi. that two of the 11 had been smash by one of the discs. The remaini? nine I placed in a slight depressi that I made for them in the work soil of the previous round. When came around to the spot again abo fifteen minutes later there w 